\title{
The Relationship Between the Recovery of Balance and Cognitive Functions During Physiotherapy in Patients with Traumatic Brain Injury
}

\author{
E. Lendraitienė \\ U. Buraitytė \\ D. Petruševičienė \\ L. Varžaitytė \\ Lithuanian University \\ of Health Sciences, \\ Department of Rehabilitation
}

\begin{abstract}
Summary. Background. There is growing evidence that cognitive and motor functions after traumatic brain injury (TBI) are actually related. However, we failed to find any concrete evidence proving the interrelationship between balance and cognitive functions therefore the effects of TBI on cognitive and motor functions remain not fully evaluated.

Objective. The aim of the study was to evaluate the relationship between the recovery of balance and cognitive functions during physiotherapy in patients with TBI.

The Methods of the study. The study included 25 individuals who had sustained TBI. The subjects were distributed into two groups: Group 1 consisted of 15 subjects with moderate TBI, and Group 2 - of 10 subjects with severe TBI. The cognitive functions were evaluated using the Mini Mental State Examination, the level of cognitive functioning (consciousness) was evaluated using the Rancho Los Amigos scale, and balance was assessed with the help of the Fullerton Advanced Balance Scale.

Results and conclusions. After physiotherapy, improvement was observed in the balance of subjects with moderate and severe TBI. Physiotherapy improved cognitive functions in subjects with moderate and severe TBI. The search for correlations between individual items on the Fullerton Advanced Balance Scale and Mini Mental State Examination revealed relationship between some items in both groups.
\end{abstract}

Keywords: traumatic brain injury, balance, cognitive functions, physiotherapy.

\section{INTRODUCTION}

In recent years, studies focusing on traumatic brain injury (TBI) have been attracting increasing attention worldwide [1]. According to various authors, TBI will become the main cause of death and disability by 2020 [2]. According to Almeida T et al., TBI may cause limb paralysis, muscle tone alterations, ataxia, and sensory and balance disorders. TBI may also impair speech and cognitive functions causing changes in attention and focusing ability, learning capacity, object recognition, and special perception [3]. According to Massenzo T and Pidcoe $\mathrm{P}$, early rehabilitation is

\author{
Address: \\ Egle Lendraitiene \\ Lithuanian University of Health Sciences, \\ Department of Rehabilitation \\ Eiveniu g. 2, LT-50161 Kaunas \\ Email: egle.lendraitiene@lsmuni.lt
}

necessary to prevent such impairments [4]. The recovery of cognitive and motor functions after TBI has attracted significant attention. Disturbances in balance and posture control are common causes of falls in post-TBI patients limiting such patients' autonomy and independence in daily activities. For this reason, the recovery of balance is one of the first goals of primary rehabilitation in post-TBI patients [5]. Cognitive dysfunction is an equally important problem in such patients. According to Chen A, cognitive dysfunction is the most common impairment after TBI [6]. For these reasons, cognitive rehabilitation involving both the recovery and the compensation of the lost functions is essential in post-TBI patients [7]. The results of some studies indicate that cognitive and motor functions are interrelated [8-10]. However, we failed to find any concrete evidence proving the interrelationship between balance and cognitive functions. Therefore, in this study, we searched for associations between the recovery of balance and cognitive functions during physiotherapy in post-TBI patients.

(C) Neurologijos seminarai, 2018. Open Access. This article is distributed under the terms of the Creative Commons Attribution 4.0 International License CC-BY 4.0 (http://creativecommons.org/licenses/by/4.0/), which permits unrestricted use, distribution, and reproduction in any medium, provided you give appropriate credit to the original author(s) and the source, provide a link to the Creative Commons license, and indicate if changes were made. 
The results of this study may be important in determining the relationship between balance and cognitive functions as well as the strength and significance of this association in the rehabilitation process.

\section{OBJECTIVE}

The aim of the study was to evaluate the relationship between the recovery of balance and cognitive functions during physiotherapy in patients with TBI.

\section{MATERIAL AND METHODS}

The study was performed at the Hospital of the Lithuanian University of Health Sciences (with the permission of the Bioethics Center No. BEC-KH(B)-23). The study included 25 subjects who had sustained TBI and had residual moderate or mild cognitive dysfunction according to the Mini Mental State Examination (MMSE). By the severity of the injury, the subjects were distributed into two groups: Group 1 consisted of 15 subjects with moderate TBI (mean age $-66.4 \pm 12.3$ years) and Group 2 - of 10 subjects with severe TBI (mean age $-45.8 \pm 20.5$ years). In both groups, the study was conducted in three stages. During the first stage, the subjects' condition was evaluated prior to physiotherapy, using the Fullerton Advanced Balance (FAB) Scale, the MMSE, and the Rancho Los Amigos (RLA) scale for evaluating the level of cognitive functioning (consciousness).

During the second stage of the study, tools and methods for the development of balance and cognitive functions were applied in both groups of patients. During balance improvement, the patients performed such exercises as standing with feet together and eyes open or closed, standing on one leg, various exercises on unstable surfaces and balls, walking over obstacles, and various manipulation movements performed while walking - such as throwing balls, carrying weight in one hand, and reaching for an object in different locations, continuously changing the pace. During physiotherapy, depending on the type of cognitive dysfunction, various grammar, mathematic, verbal, logical, and practical tasks were used, thus gradually teaching and training the patients to think independently and to perform certain actions. Each patient underwent physiotherapy procedures once daily, five times per week. The duration of each procedure was $30 \mathrm{~min}$.

During the third stage, the evaluation of balance and cognitive functions was repeated using the same methods that were applied prior to physiotherapy.

Cognitive functions were evaluated using the MMSE designed for the evaluation of the general level of cognitive functions. This tool evaluates orientation, memory, calculation, reading and writing, visual-spatial, and language abilities. The test consists of 11 tasks with the total maximal score of 30 points. Depending on the final score, the following levels of cognitive impairment are identified:

- 0 - 10 - severe cognitive impairment;

- 11 - 20 - moderate cognitive impairment;

- 21 - 24 - mild cognitive impairment;

- $\geq 25$ - no cognitive impairment [11-14].

We also evaluated the level of cognitive functioning (consciousness) using the RLA scale. The scale consists of 8 levels and is designed for the evaluation of post-TBI patients' overall level of consciousness, cognitive functions, and behavior. The levels of the test are the following:

1. No response;

2. Generalized response;

3. Localized response;

4. Confused, agitated response;

5. Confused, inappropriate response;

6. Confused, appropriate response;

7. Automatic, appropriate response;

8. Purposeful, appropriate response $[1,16]$.

To evaluate the subjects' balance, the Fullerton Advanced Balance (FAB) scale was selected. The FAB scale is designed for the evaluation of static and dynamic balance. The test consists of 10 tasks, each of which is evaluated from 4 to 0 points, where 0 points mean that the patient is unable to perform the task, and 4 points - normal movement and postural control. The maximal possible score is 40 points. The FAB scale is used to evaluate such skills as the ability to stand with feet together and eyes closed, to reach forward to retrieve an object, to turn 360 degrees in left and right directions, to step onto and over a bench, to perform tandem walk, to stand on one leg, to stand on foam with eyes closed, to perform a two-footed jump, to walk with head turns, and to maintain reactive postural control [17].

Statistical data analysis was performed using SPSS.21 for Windows statistical software package and Microsoft Excel 2010 software. Two dependent samples were analyzed by applying the non-parametric Wilcoxon criterion, and the linear relationship between the variables was determined by calculating Spearman's correlation coefficient. The relationship was considered to be weak when $|r|<0.2$, moderate - when $0.2 \leq r \mid \leq 0.06$, and strong - when $|r|>0.6$. The data were presented as mean \pm standard deviation. When comparing distributions, the difference was considered to be statistically significant when $\mathrm{p}<0.05$.

\section{RESULTS}

\section{The results of the Fullerton Advanced Balance scale in Group 1}

Before physiotherapy, the mean score of the FAB scale in Group 1 was $20.1 \pm 7.9$ points, and after physiotherapy $30.3 \pm 6.3$ points. A statistically significant $(Z=-3.4$; $\mathrm{p}=0.001)$ improvement in balance was observed. The evaluation of the scores in individual tasks of the FAB scale in 
Reactive postural control

Walk with head turns

Two-footed jump

Stand on foam with eyes closed

Stand on one leg

Tandem walk

Step onto and over a bench

Turn 360 degrees in left and right directions

Reach forward to retrieve an object

Stand with feet together and eyes closed
3,7
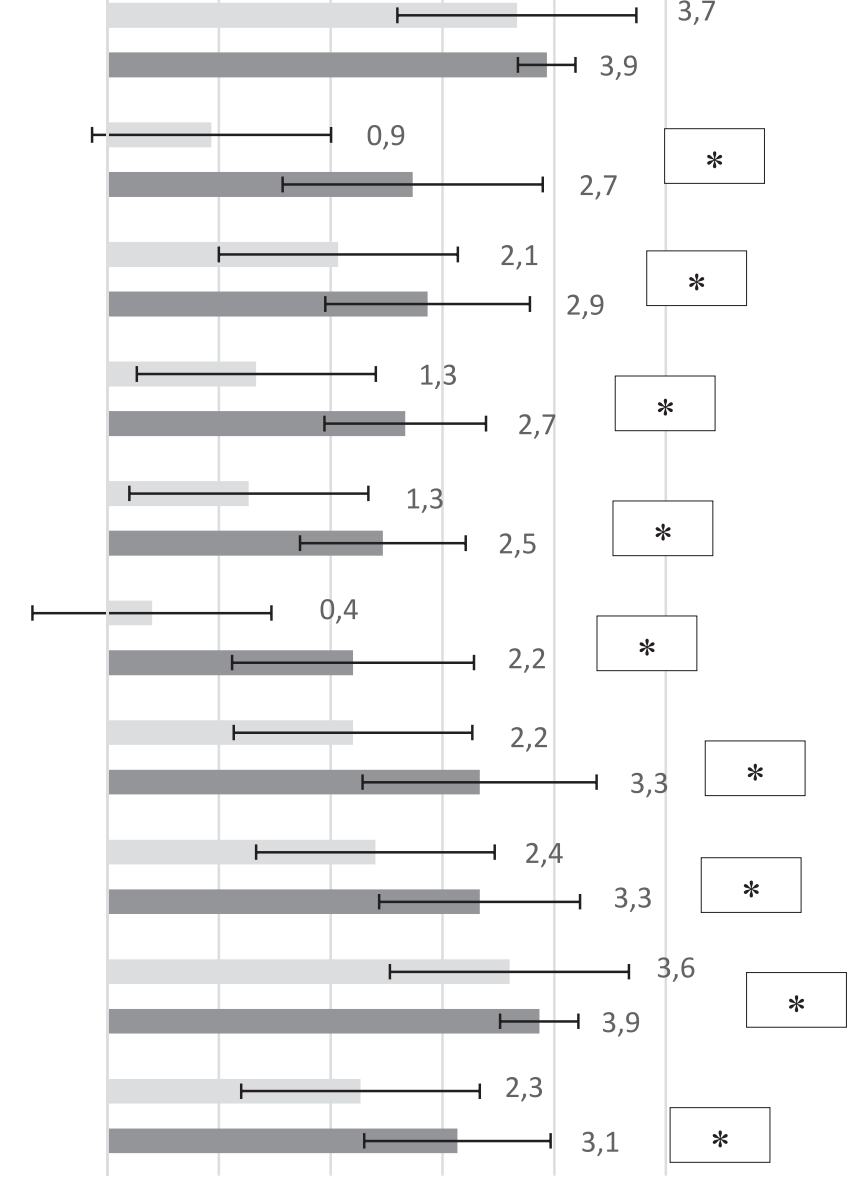

5,0

\section{Before After}

Fig. 1. Scores of individual tasks on the Fullerton Advanced Balance (FAB) scale in Group 1 before and after physiotherapy $\left({ }^{*} \mathrm{p}<0.05\right.$, when comparing distributions)

Group 1 showed a statistically significant difference $(\mathrm{p}<0.05)$ between the scores of all tasks, except for "Reactive postural control" (Fig. 1).

\section{The results of the Mini Mental State Examination in Group 1}

Before physiotherapy, the score of the MMSE in Group 1 was $20.2 \pm 3.7$ points, and after physiotherapy $24.8 \pm 3.5$ points. After physiotherapy, MMSE scores in patients with moderate TBI improved statistically significantly $(Z=-3.432 ; p=0.001)$. The evaluation of the scores in individual tasks of the MMSE in Group 1 showed that after physiotherapy, statistically significant differences emerged only in the scores of some tasks. Statistically significant differences were found only between the scores of the tasks "Orientation to time", "Attention and calculation", and "Recall" $(\mathrm{p}<0.05)$. The score of "Orientation to time" before physiotherapy was $3.33 \pm 1.2$ points and after physiotherapy $-4.0 \pm 1.4(\mathrm{Z}=-2.4 ; \mathrm{p}=0.015)$, the score of "Attention and calculation" before physiotherapy was $1.8 \pm 0.9$ points and after physiotherapy $-3.47 \pm 0.9$ points
$(\mathrm{Z}=-3.1 ; \mathrm{p}=0.002)$, and the score of "Recall" before physiotherapy was $0.53 \pm 0.8$ points and after physiotherapy $1.47 \pm 0.7$ points $(Z=-2.8 ; p=0.005)$ (Fig. 2$)$.

\section{Changes in the levels of the Rancho Los Amigos scale in Group 1 after physiotherapy}

In Group 1, the subjects' level of cognitive functioning (consciousness) ranged from 5 (confused, inappropriate response) to 8 (purposeful, appropriate response). Before physiotherapy, one respondent demonstrated confused, inappropriate response (level 5); after physiotherapy, he remained confused but the response was appropriate - i.e., he reached level 6 . In addition, one subject was at level 6 before physiotherapy, while after physiotherapy, his level of cognitive functioning (consciousness) increased to level 7 (automatic, appropriate response). The majority of the subjects (10 patients) were at level 7 (automatic, appropriate response) before physiotherapy and reached level 8 (purposeful, appropriate response) after physiotherapy, while 3 subjects who were at level 8 before physiotherapy remained at the highest level after physiotherapy procedures. 


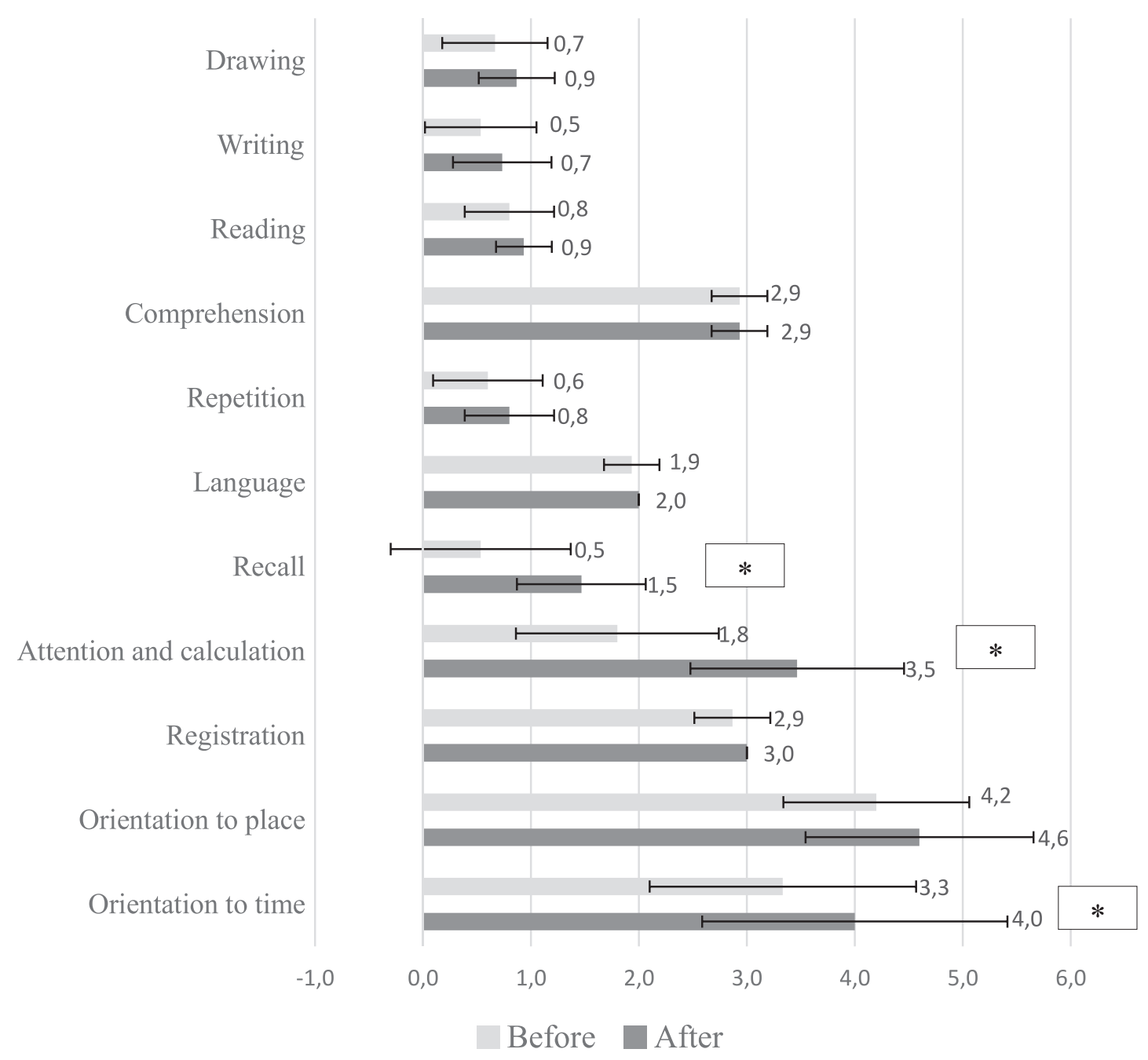

Fig. 2. Scores of individual tasks on the Mini Mental State Examination (MMSE) in Group 1 before and after physiotherapy $\left({ }^{*} \mathrm{p}<0.05\right.$, when comparing distributions)

\section{Associations between the recovery of balance and cognitive skills in Group 1}

Because of the small sample size, no associations between FAB and MMSE scores were detected after physiotherapy. However, when searching for associations between individual FAB and MMSE tasks, a statistically significant relationship was detected between some of them. After physiotherapy, a statistically significant moderately strong linear correlation was detected between the scores of the tasks "Stand with feet together and eyes closed" and "Attention and calculation" ( $\mathrm{r}=0.53 ; \mathrm{p}=0.044)$, "Stand with feet together and eyes closed" and "Drawing" ( $r=0,53 ; p=0,042)$, "Step onto and over a bench" and "Drawing" ( $\mathrm{r}=0.54$; $\mathrm{p}=0.039$ ), and between "Tandem walk" and "Recall" $(\mathrm{r}=0.54 ; \mathrm{p}=0.037)$. A statistically significant strong linear correlation was detected between the scores of the tasks "Stand with feet together and eyes closed" and "Repetition" ( $r=0.68 ; p=0.006)$, "Turn 360 degrees in left and right directions" and "Attention and calculation" $(r=0,62$; $\mathrm{p}=0,013)$, between the scores of the tasks "Turn $360 \mathrm{de}-$ grees in left and right directions" and "Drawing" ( $\mathrm{r}=0.65$; $\mathrm{p}=0.008)$, "Tandem walk" and "Drawing" $(\mathrm{r}=0.65$; $\mathrm{p}=0.009)$, and "Stand on one leg" and "Drawing" ( $\mathrm{r}=0.67$; $p=0.006)$, and between the scores of the tasks "Reactive postural control" and "Drawing" $(r=0.68 ; p=0.005)(\mathrm{Ta}-$ ble 1). The linear correlation found between these tasks suggests that an improvement in scores of these tasks on the FAB scale also improves the scores of the MMSE tasks.

\section{The results of the Fullerton Advanced Balance scale in Group 2}

The mean score of the FAB scale in Group 2 before physiotherapy was $13.3 \pm 6.7$ points and after physiotherapy $26.3 \pm 7.3$ points. A significant improvement in the balance of patients with severe TBI was observed after physiotherapy $(Z=-2.807 ; p=0.005)$. The evaluation of the scores in individual tasks of the FAB scale in Group 2 showed a statistically significant $(p<0.05)$ improvement in the scores of all tasks after physiotherapy. The score of the task "Stand with feet together and eyes closed" before physiotherapy was $1.5 \pm 0.9$ points, and after physiotherapy $-2.4 \pm 0.9$ $(\mathrm{Z}=-2.5 ; \mathrm{p}=0.011)$. Before physiotherapy, the score of the task "Reach forward to retrieve an object" in Group 2 subjects was $3.0 \pm 1.05$ points and after physiotherapy - 
Table 1. Correlation between scores on individual tasks of the Fullerton Advanced Balance (FAB) scale and the Mini Mental State Examination (MMSE) in Group 1 after physiotherapy

\begin{tabular}{|c|c|c|c|c|c|c|c|c|c|c|c|}
\hline & 泀 & 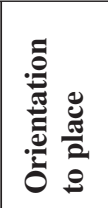 & 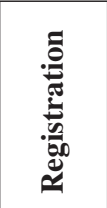 & 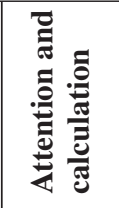 & 馬 & 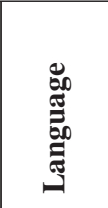 & 串 & 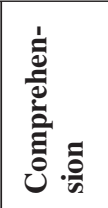 & : & 先 & 茪 \\
\hline $\begin{array}{l}\text { Stand with feet together } \\
\text { and eyes closed }\end{array}$ & $\mathrm{p}>0.05$ & $\mathrm{p}>0.05$ & $p>0.05$ & $\mathrm{r}=0.53 *$ & $\mathrm{p}>0.05$ & $\mathrm{p}>0.05$ & $\mathrm{r}=0.68 * *$ & $\mathrm{p}>0.05$ & $\mathrm{p}>0.05$ & $\mathrm{p}>0.05$ & $\mathrm{r}=0.53 *$ \\
\hline $\begin{array}{l}\text { Reach forward to retrieve } \\
\text { an object }\end{array}$ & $\mathrm{p}>0.05$ & $\mathrm{p}>0.05$ & $\mathrm{p}>0.05$ & $\mathrm{p}>0.05$ & $\mathrm{p}>0.05$ & $\mathrm{p}>0.05$ & $\mathrm{p}>0.05$ & $\mathrm{p}>0.05$ & $p>0.05$ & $\mathrm{p}>0.05$ & $\mathrm{p}>0.05$ \\
\hline $\begin{array}{l}\text { Turn } 360 \text { degrees in left } \\
\text { and right directions }\end{array}$ & $\mathrm{p}>0.05$ & $\mathrm{p}>0.05$ & $\mathrm{p}>0.05$ & $\mathrm{r}=0.62 *$ & $\mathrm{p}>0.05$ & $\mathrm{p}>0.05$ & $\mathrm{p}>0.05$ & $\mathrm{p}>0.05$ & $\mathrm{p}>0.05$ & $\mathrm{p}>0.05$ & $\mathrm{r}=0.65^{* *}$ \\
\hline Step onto and over a bench & $\mathrm{p}>0.05$ & $\mathrm{p}>0.05$ & $\mathrm{p}>0.05$ & $\mathrm{p}>0.05$ & $\mathrm{p}>0.05$ & $\mathrm{p}>0.05$ & $\mathrm{p}>0.05$ & $\mathrm{p}>0.05$ & $p>0.05$ & $\mathrm{p}>0.05$ & $\mathrm{r}=0.54$ * \\
\hline Tandem walk & $\mathrm{p}>0.05$ & $\mathrm{p}>0.05$ & $\mathrm{p}>0.05$ & $\mathrm{p}>0.05$ & $\mathrm{r}=0.54 *$ & $\mathrm{p}>0.05$ & $\mathrm{p}>0.05$ & $\mathrm{p}>0.05$ & $\mathrm{p}>0.05$ & $\mathrm{p}>0.05$ & $\mathrm{r}=0.65^{* *}$ \\
\hline Stand on one leg & $\mathrm{p}>0.05$ & $\mathrm{p}>0.05$ & $\mathrm{p}>0.05$ & $\mathrm{p}>0.05$ & $\mathrm{p}>0.05$ & $\mathrm{p}>0.05$ & $\mathrm{p}>0.05$ & $\mathrm{p}>0.05$ & $\mathrm{p}>0.05$ & $\mathrm{p}>0.05$ & $\mathrm{r}=0.67 * *$ \\
\hline $\begin{array}{l}\text { Stand on foam with eyes } \\
\text { closed }\end{array}$ & $\mathrm{p}>0.05$ & $\mathrm{p}>0.05$ & $p>0.05$ & $p>0.05$ & $\mathrm{p}>0.05$ & $\mathrm{p}>0.05$ & $\mathrm{p}>0.05$ & $\mathrm{p}>0.05$ & $p>0.05$ & $\mathrm{p}>0.05$ & $\mathrm{p}>0.05$ \\
\hline Two-footed jump & $\mathrm{p}>0.05$ & $\mathrm{p}>0.05$ & $p>0.05$ & $p>0.05$ & $\mathrm{p}>0.05$ & $\mathrm{p}>0.05$ & $\mathrm{p}>0.05$ & $\mathrm{p}>0.05$ & $p>0.05$ & $\mathrm{p}>0.05$ & $\mathrm{p}>0.05$ \\
\hline Walk with head turns & $\mathrm{p}>0.05$ & $\mathrm{p}>0.05$ & $\mathrm{p}>0.05$ & $\mathrm{p}>0.05$ & $\mathrm{p}>0.05$ & $\mathrm{p}>0.05$ & $\mathrm{p}>0.05$ & $\mathrm{p}>0.05$ & $\mathrm{p}>0.05$ & $\mathrm{p}>0.05$ & $\mathrm{p}>0.05$ \\
\hline Reactive postural control & $\mathrm{p}>0.05$ & $\mathrm{p}>0.05$ & $p>0.05$ & $\mathrm{p}>0.05$ & $\mathrm{p}>0.05$ & $\mathrm{p}>0.05$ & $\mathrm{p}>0.05$ & $\mathrm{p}>0.05$ & $p>0.05$ & $\mathrm{p}>0.05$ & $\mathrm{r}=0.68 * *$ \\
\hline
\end{tabular}

*Statistically significant correlation when $\mathrm{p}<0.05$;

$* *$ Statistically significant correlation when $p<0.01$

Reactive postural control

Walk with head turns

Two-footed jump

Stand on foam with eyes closed

Stand on one leg

Tandem walk

Step onto and over a bench

Turn 360 degrees in left and right directions

Reach forward to retrieve an object

Stand with feet together and eyes closed $-1,0$
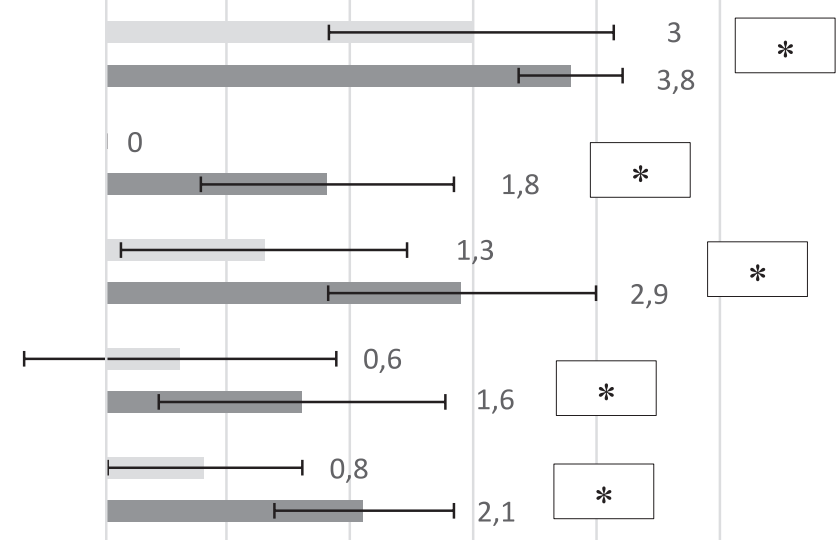

0
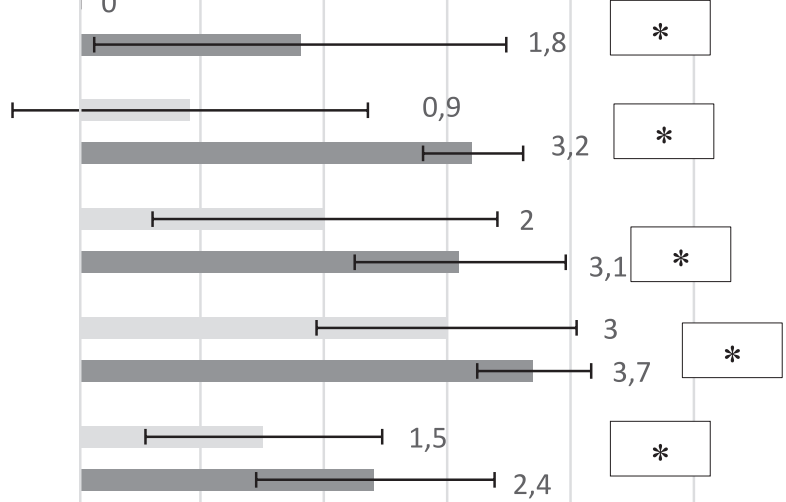

$\begin{array}{llllll}0,0 & 1,0 & 2,0 & 3,0 & 4,0 & 5,0\end{array}$

\section{Before $\square$ After}

Fig. 3. Scores of individual tasks on the Fullerton Advanced Balance (FAB) scale in Group 2 before and after physiotherapy $\left({ }^{*} \mathrm{p}<0.05\right.$, when comparing distributions) 


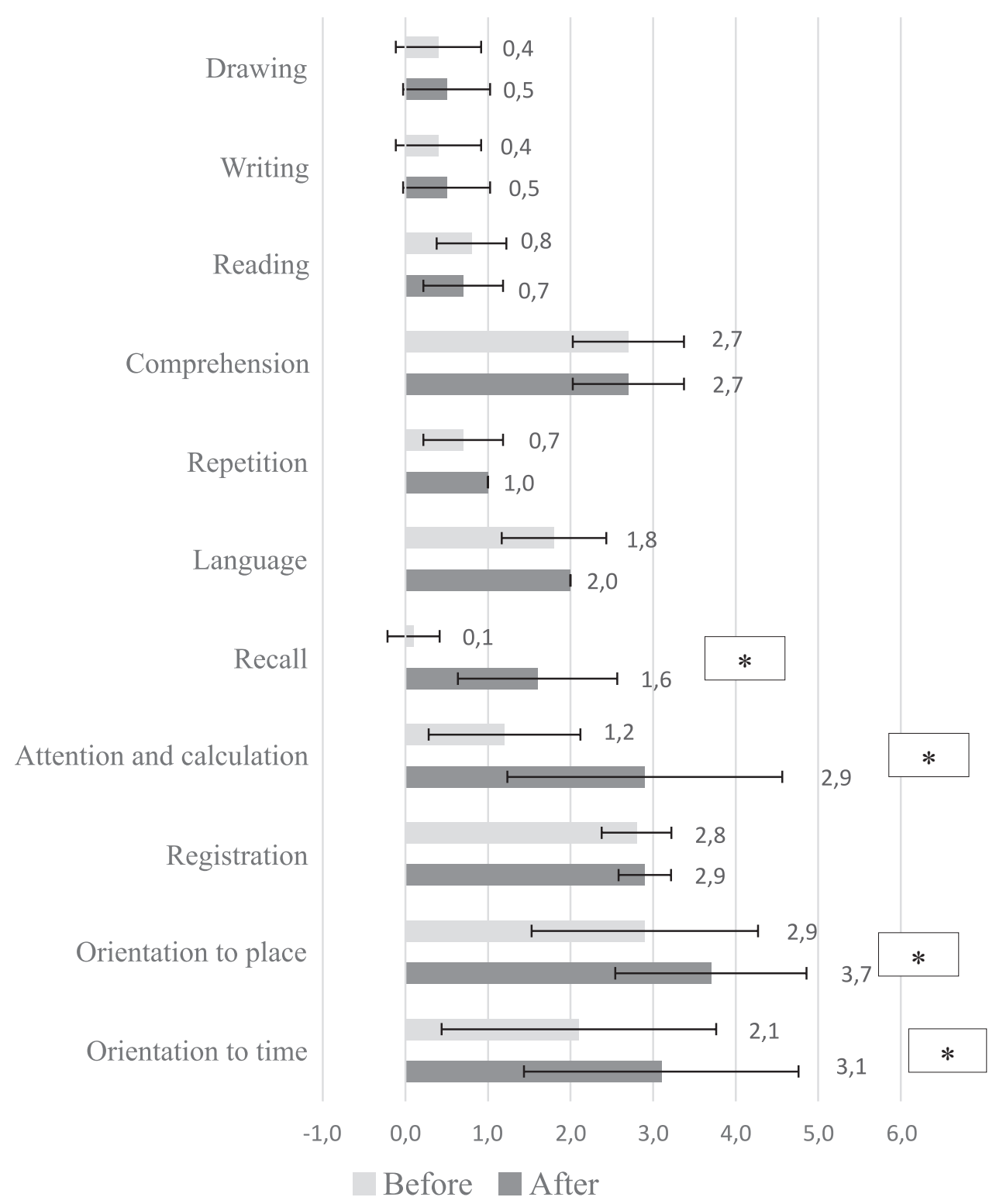

Fig. 4. Scores of individual tasks on the Mini Mental State Examination (MMSE) in Group 2 before and after physiotherapy $\left({ }^{*} \mathrm{p}<0.05\right.$, when comparing distributions $)$

$3.7 \pm 0.5$ points $(\mathrm{Z}=-2.1 ; \mathrm{p}=0.038)$. The score of the task "Turn 360 degrees in left and right directions" before physiotherapy was $2.0 \pm 1.4$ points and after physiotherapy $3.1 \pm 0.9$ points $(Z=-2.6 ; p=0.009)$. The score of the task "Step onto and over a bench" before physiotherapy was $0.9 \pm 1.4$ points and after physiotherapy, the score was $3.2 \pm 0.4$ points $(\mathrm{Z}=-2.8 ; \mathrm{p}=0.005)$. The score of the task "Tandem walk" before physiotherapy was $0 \pm 0$ points and after physiotherapy $-1.8 \pm 1.7$ points $(\mathrm{Z}=-2.2 ; \mathrm{p}=0.026)$. The score of the task "Stand on one leg" before physiotherapy was $0.8 \pm 0.8$ points and after physiotherapy $2.1 \pm 0.7$ points $(Z=-2.9 ; p=0.004)$. The score of the task "Stand on foam with eyes closed" before physiotherapy was $0.6 \pm 1.3$ points and after physiotherapy $1.6 \pm 1.2$ points $(Z=-2.2 ; p=0.026)$. The score of the task "Two-footed jump" before physiotherapy was $1.3 \pm 1.2$ points and after physiotherapy $-2.9 \pm 1.1$ points $(\mathrm{Z}=-2.7 ; \mathrm{p}=0.007)$. The score of the task "Walk with head turns" before physiotherapy was $0 \pm 0$ points and after physiotherapy $-1.8 \pm 1.0$ points $(\mathrm{Z}=-2.8 ; \mathrm{p}=0.006)$. Finally, the score of the task "Reactive postural control" before physiotherapy was $3 \pm 1.2$ points and after physiotherapy $-3.8 \pm 0.4$ ( $Z=-2.3 ; p=0.023$ ) (Fig. 3).

\section{The results of the Mini Mental State Examination in Group 2}

In Group 2, the mean total score of the MMSE before physiotherapy was $15.9 \pm 5.2$ and after physiotherapy $21.6 \pm 6.1$ points. A statistically significant improvement in the mental state of patients with severe TBI was observed $(Z=-2.829 ; p=0.005)$. The evaluation of the scores in individual tasks of the MMSE in Group 2 after physiotherapy revealed statistically significant differences $(p<0.05)$ in the scores of the same tasks as in Group 1 ("Orientation to time", "Attention and calculation", and "Recall"); in addi- 
Table 2. Correlation between scores of individual tasks on the Fullerton Advanced Balance (FAB) scale and the Mini Mental State Examination (MMSE) in Group 2 after physiotherapy

\begin{tabular}{|c|c|c|c|c|c|c|c|c|c|c|c|}
\hline & 泀 & 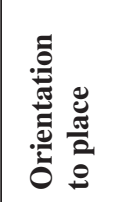 & 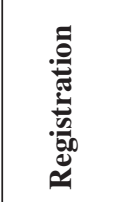 & 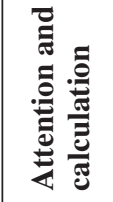 & 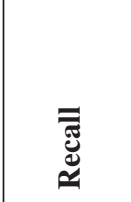 & 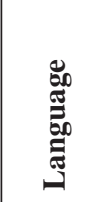 & : & 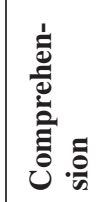 & 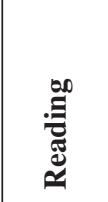 & 盗 & 苞 \\
\hline $\begin{array}{l}\text { Stand with feet together } \\
\text { and eyes closed }\end{array}$ & $p>0.05$ & $r=0.63 *$ & $\mathrm{p}>0.05$ & $\mathrm{p}>0.05$ & $\mathrm{r}=0.78 * *$ & $\mathrm{p}>0.05$ & $p>0.05$ & $\mathrm{p}>0.05$ & $p>0.05$ & $p>0.05$ & $r=0.66^{*}$ \\
\hline $\begin{array}{l}\text { Reach forward to retrieve } \\
\text { an object }\end{array}$ & $\mathrm{p}>0.05$ & $\mathrm{p}>0.05$ & $\mathrm{p}>0.05$ & $\mathrm{p}>0.05$ & $\mathrm{p}>0.05$ & $\mathrm{p}>0.05$ & $p>0.05$ & $\mathrm{p}>0.05$ & $\mathrm{p}>0.05$ & $p>0.05$ & $\mathrm{p}>0.05$ \\
\hline $\begin{array}{l}\text { Turn } 360 \text { degrees in left } \\
\text { and right directions }\end{array}$ & $\mathrm{p}>0.05$ & $\mathrm{p}>0.05$ & $\mathrm{p}>0.05$ & $\mathrm{p}>0.05$ & $\mathrm{r}=0.72 *$ & $\mathrm{p}>0.05$ & $p>0.05$ & $\mathrm{p}>0.05$ & $p>0.05$ & $p>0.05$ & $\mathrm{p}>0.05$ \\
\hline Step onto and over a bench & $\mathrm{p}>0.05$ & $\mathrm{p}>0.05$ & $\mathrm{p}>0.05$ & $r=0.64^{*}$ & $\mathrm{p}>0.05$ & $\mathrm{p}>0.05$ & $\mathrm{p}>0.05$ & $\mathrm{p}>0.05$ & $\mathrm{p}>0.05$ & $\mathrm{p}>0.05$ & $\mathrm{p}>0.05$ \\
\hline Tandem walk & $\mathrm{p}>0.05$ & $p>0.05$ & $\mathrm{p}>0.05$ & $\mathrm{p}>0.05$ & $\mathrm{r}=0.75^{*}$ & $\mathrm{p}>0.05$ & $\mathrm{p}>0.05$ & $\mathrm{p}>0.05$ & $\mathrm{p}>0.05$ & $\mathrm{p}>0.05$ & $\mathrm{p}>0.05$ \\
\hline Stand on one leg & $p>0.05$ & $\mathrm{p}>0.05$ & $\mathrm{p}>0.05$ & $\mathrm{p}>0.05$ & $\mathrm{r}=0.72 *$ & $\mathrm{p}>0.05$ & $\mathrm{p}>0.05$ & $\mathrm{p}>0.05$ & $p>0.05$ & $p>0.05$ & $\mathrm{p}>0.05$ \\
\hline $\begin{array}{l}\text { Stand on foam with eyes } \\
\text { closed }\end{array}$ & $\mathrm{p}>0.05$ & $\mathrm{p}>0.05$ & $\mathrm{p}>0.05$ & $\mathrm{p}>0.05$ & $\mathrm{p}>0.05$ & $\mathrm{p}>0.05$ & $p>0.05$ & $\mathrm{p}>0.05$ & $\mathrm{p}>0.05$ & $p>0.05$ & $\mathrm{p}>0.05$ \\
\hline Two-footed jump & $\mathrm{p}>0.05$ & $\mathrm{p}>0.05$ & $\mathrm{p}>0.05$ & $\mathrm{p}>0.05$ & $\mathrm{r}=0.76^{*}$ & $\mathrm{p}>0.05$ & $\mathrm{p}>0.05$ & $\mathrm{p}>0.05$ & $\mathrm{p}>0.05$ & $\mathrm{p}>0.05$ & $\mathrm{p}>0.05$ \\
\hline Walk with head turns & $\mathrm{p}>0.05$ & $\mathrm{p}>0.05$ & $\mathrm{p}>0.05$ & $\mathrm{p}>0.05$ & $\mathrm{p}>0.05$ & $\mathrm{p}>0.05$ & $\mathrm{p}>0.05$ & $\mathrm{p}>0.05$ & $\mathrm{p}>0.05$ & $\mathrm{p}>0.05$ & $\mathrm{p}>0.05$ \\
\hline Reactive postural control & $\mathrm{p}>0.05$ & $p>0.05$ & $\mathrm{r}=0.67^{*}$ & $\mathrm{p}>0.05$ & $\mathrm{p}>0.05$ & $\mathrm{p}>0.05$ & $p>0.05$ & $\mathrm{p}>0.05$ & $\mathrm{p}>0.05$ & $p>0.05$ & $\mathrm{p}>0.05$ \\
\hline
\end{tabular}

*Statistically significant correlation when $\mathrm{p}<0.05$;

** Statistically significant correlation when $\mathrm{p}<0.01$

tion, a statistically significant $(\mathrm{p}<0.05)$ improvement was observed in the score of the task "Orientation to place", which was not observed in Group 1. The score of the task "Orientation to time" before physiotherapy was $2.1 \pm 1.6$ points and after physiotherapy $-3.1 \pm 1.6$ points $(\mathrm{Z}=-2.5 ; \mathrm{p}=0.011)$, the score of the task "Orientation to place" before physiotherapy $-2.9 \pm 1.4$ points and after physiotherapy $-3.7 \pm 1.2$ points $(\mathrm{Z}=-2.8 ; \mathrm{p}=0.005)$, the score of the task "Attention and calculation" before physiotherapy was $1.2 \pm 0.9$ points and after physiotherapy $2.9 \pm 1.7$ points $(Z=-2.6 ; p=0.01)$, and the score of the task "Recall" before physiotherapy was $0.1 \pm 0.3$ points and after physiotherapy $-1.6 \pm 0.9$ points $(Z=-2.7 ; p=0.007)$. No statistically significant changes $(\mathrm{p} \geq 0.05)$ were observed in the scores of tasks "Registration", "Language", "Repetition", "Comprehension", "Reading", "Writing", and "Drawing". The score of the task "Registration" before physiotherapy was $2.8 \pm 0.4$ points and after physiotherapy $-2.9 \pm 0.3$ points $(Z=-1.0 ; p=0.317)$, the score of the task "Language" before physiotherapy was $1.8 \pm 0.6$ points and after physiotherapy $-2.0 \pm 0$ points $(\mathrm{Z}=-1.0 ; \mathrm{p}=0.317)$, and the score of the task "Repetition" before physiotherapy was $0.7 \pm 0.5$ points and after physiotherapy $-1.0 \pm 0$ points $(\mathrm{Z}=-1.7 ; \mathrm{p}=0.083)$. The score of the task "Comprehension" remained the same before and after physiotherapy $2.7 \pm 0.7(Z=-0.0 ; p=1.0)$. The score of the task "Reading" before physiotherapy was $0.8 \pm 0.4$ points and after physiotherapy $-0.7 \pm 0.5$ points $(Z=-1.0 ; p=0.317)$, the score of the task "Writing" before physiotherapy was $0.4 \pm 0.5$ points and after physiotherapy $-0.5 \pm 0.5$ points $(\mathrm{Z}=-1.0 ; \mathrm{p}=0.317)$, and the score of the task "Drawing" before physiotherapy was $0.4 \pm 0.5$ points and after physiotherapy $-0.5 \pm 0.5$ points $(Z=-1.0 ; p=0.317)$ (Fig. 4$)$.
Changes in the levels of the Rancho Los Amigos scale in Group 2 after physiotherapy

Before physiotherapy, four subjects in Group 2 demonstrated confused, inappropriate response (level 5), while after physiotherapy, three of them reached level 6 (confused, appropriate response) and one - level 7 (automatic, appropriate response). Of three patients who were at level 6 (confused, appropriate response) before physiotherapy, one reached level 7 (automatic, appropriate response) and two - level 8 (purposeful, appropriate response). The majority of the subjects (3) were at level 7 (automatic, appropriate response) before physiotherapy and they reached level 8 (purposeful, appropriate response) of cognitive functioning (consciousness) after physiotherapy.

\section{Associations between the recovery of balance and cognitive skills in Group 2}

After physiotherapy, statistically significant strong linear correlations in Group 2 were found between the scores of the tasks "Stand with feet together and eyes closed" and "Orientation to place" $(r=0.63 ; p=0.04)$, "Stand with feet together and eyes closed" and "Recall" ( $r=0,78 ; p=0,01)$, "Stand with feet together and eyes closed" and "Drawing" ( $r=0.66$; $\mathrm{p}=0.039$ ), between the scores of the tasks "Turn 360 degrees in left and right directions" and "Recall" ( $\mathrm{r}=0.72 ; \mathrm{p}=0.019)$, "Step onto and over a bench" and "Attention and calculation" $(\mathrm{r}=0.64 ; \mathrm{p}=0.047)$, "Tandem walk" and "Recall" ( $\mathrm{r}=0.75$; $\mathrm{p}=0.012)$, "Stand on one leg" and "Recall" ( $\mathrm{r}=0.72$; $\mathrm{p}=0.019)$, "Two-footed jump" and "Recall" ( $\mathrm{r}=0.76$; $\mathrm{p}=0.011$, and between the scores of the tasks "Reactive postural control" and "Registration" ( $r=0.67 ; \mathrm{p}=0.035)$ (Table 2$)$. 


\section{DISCUSSION}

The evaluation of the subjects' condition after physiotherapy using all three clinical tests showed a statistically significant $(\mathrm{p}<0.05)$ improvement in FAB and MMSE scores in both Group 1 and Group 2. The analysis of the RLA scores also showed that the level of cognitive functioning (consciousness) improved in all subjects after physiotherapy. In the majority of our subjects, physiotherapy was applied for at least 5 days, and a statistically significant $(\mathrm{p}<0.05) \mathrm{im}-$ provement in MMSE scores was observed within this period. Our results are in line with those presented in scientific literature - the results of the published studies showed that the recovery of cognitive functions occurs within the first few weeks or months after TBI [17]. The analysis of the changes in the levels of the RLA scale before and after physiotherapy showed that the majority of the subjects in the group of patients with moderate TBI were at level 7 on the RLA scale before physiotherapy, and all these subjects reached level 8 (the highest level) of cognitive functioning (consciousness) after physiotherapy. Meanwhile, in the groups of patients with severe TBI, the majority of the subjects before physiotherapy were at level 5 ( 3 subjects) and level 7 (3 subjects). Patients who before physiotherapy were at level 5, reached level 6 after physiotherapy and subjects with level 7 at baseline reached level 8 (the highest level) after physiotherapy. The generalized survey of the obtained results showed that in patients after severe TBI, the level of cognitive functioning (consciousness) was lower and functional recovery took longer and was more complicated than in patients with moderate TBI. However, severe trauma does not always result in severe functional impairment, as indicated by the presence of subjects with level 7 on the RLA scale in the group of patients with severe TBI, while such level of cognitive functioning (consciousness) should be more characteristic of patients with milder TBI. However, we failed to find any studies that would analyze changes in the levels of the RLA scale prior to and after physiotherapy in post-TBI patients, and thus we cannot compare our results with those of other authors. The scores on the FAB scale improved statistically significantly $(p<0.05)$ in both Group 1 and Group 2 after physiotherapy. The evaluation of the scores in individual tasks of the FAB scale in Group 1 after physiotherapy showed a statistically significant difference $(\mathrm{p}<0.05)$ between the scores of all tasks, except for "Reactive postural control" - there was no statistically significant improvement $(\mathrm{p} \geq 0.05)$ in the score of this task after physiotherapy. We think that this is because TBI affects CNS centers that control muscle synergies responsible for body response and posture as well as for respective movements of the head, eyes, torso, and extremities. The generalized survey of data of Group 2 showed a statistically significant $(p<0.05)$ difference in the scoring of all tasks after physiotherapy. We failed to find any studies that apply the FAB scale in post-TBI patients, but this tool is successfully applied in the evaluation of patients with other types of neurological disorders - e.g. in post-stroke patients or those with Parkinson's disease [17].
The analysis of the correlation between balance and cognitive functions after physiotherapy revealed no statistically significant relationship between these markers $(\mathrm{p} \geq 0.05)$. However, a more detailed analysis of correlations between individual tasks of the FAB and MMSE scales showed statistically significant $(p<0.05)$ moderate or even strong correlations between some tasks of the aforementioned tests. Such distribution of the data may be explained by the small size of the sample. Perhaps the study on the correlation between balance and cognitive functions should be carried out in several healthcare units and for a longer period of time. The survey of literature sources shows that several authors state that motor and cognitive functions are interrelated [8,9]. During recent years, an increasing body of evidence has suggested that nerve regions associated with cognitive functions may also be involved in the performance of motor tasks [8]. Executive functions and attention may also be related to motor functions in post-TBI patients [10]. Spitz G et al. performed a study to determine the relationship between patients' cognitive functions and functional results. The results of the study showed that during the first years after TBI, functional results were more affected by cognitive functions than by demographic characteristics or the severity of the trauma and that the executive functions had the strongest effect on the patients' functional results [19]. Saverino A et al. performed a study with the aim of determining the relationship between cognitive functions (especially executive functions) and balance and the risk of falls in patients with neurological diseases. The results of the study showed that executive functions were more associated with the risk of falls, whereas the impairment of cognitive functions in general was associated with balance impairment [19]. Even though the studies found in literature do not analyze the relationship between balance and cognitive functions, and thus we cannot compare our results with those of other authors, the results of the analysis of literature and other studies suggest that the relationship between cognitive and motor functions is attracting researchers' increasing attention not only in the studies on TBI, but also in those on other neurological disorders. For this reason, our research as well as other studies in this field may serve as an encouragement for further more detailed studies on the association between the recovery of balance and cognitive functions.

\section{CONCLUSIONS}

1. After physiotherapy, improvement was observed in the balance of subjects with moderate and severe traumatic brain injury.

2. Physiotherapy improved cognitive functions in subjects with moderate and severe traumatic brain injury.

3. The search for correlations between individual items on the Fullerton Advanced Balance Scale and Mini Mental State Examination revealed relationship between some items in both groups. 


\section{References}

1. Sjölund BH. The complexity of traumatic brain injury. Journal of Rehabilitation Medicine 2013; 45: 708-9. https://doi.org/10.2340/16501977-1216

2. Mollayeva T, Kendzerska T, Mollayeva S, Shapiro CM, Colantonio A, Cassidy JD. A systematic review of fatigue in patients with traumatic brain injury: the course, predictors and consequences. Neuroscience and Biobehavioral Reviews 2014; 47: 684-716. https://doi.org/10.1016/ j.neubiorev.2014.10.024

3. Almeida TLT, Falkenburg L, Nascimento RZR, Reis CA, Sales VC, Pedroso TD, et al. Traumatic brain injury: rehabilitation. Acta Fisiatrica 2012; 19(2): 130-7. https://doi.org/ 10.5935/0104-7795.20120020

4. Massenzo T, Pidcoe PE. Investigating the impact of visual biofeedback on postural control via informative dynamic balance training in healthy individuals. International Journal of Physical Medicine \& Rehabilitation 2015; 3: 275.

5. Llorens R, Colomer-Font C, Alcaniz M, Noe-Sebastian E. BioTrak virtual reality system: effectiveness and satisfaction analysis for balance rehabilitation in patients with brain injury. Neurologia 2013; 28(5): 268-75. https://doi.org/ 10.1016/j.nrleng.2012.04.016

6. Chen AJW, Novakovic-Agopian T. Interventions to improve cognitive functioning after TBI. In: Tsao JW, ed. Traumatic brain injury: a clinician's guide to diagnosis, management, and rehabilitation. Springer, 2012; 273-305. https://doi.org/ 10.1007/978-0-387-87887-4

7. Freire FR, Coelho F, Lacerda JR, da Silva MF, Gonçalves VT, Machado S, et al. Cognitive rehabilitation following traumatic brain injury. Dementia e Neuropsychologia 2011; 5(1): 17-25. https://doi.org/10.1590/S1980-57642011DN05010004

8. Sarajuuri J, Pasanen M, Rinne M, Vartiainen M, Lehto T, Alaranta $\mathrm{H}$. Relationship between cognitive and motor performance in physically well-recovered men with traumatic brain injury. Journal of Rehabilitation Medicine 2013; 45(1): 38-46. https://doi.org/10.2340/16501977-1060

9. Sosnoff JJ, Broglio SP, Ferrara MS. Cognitive and motor function are associated following mild traumatic brain injury. Experimental Brain Research 2008; 187(4): 563-71. https://doi.org/10.1007/s00221-008-1324-x

10. Tsaousides T, Gordon WA. Cognitive rehabilitation following traumatic brain injury: assessment to treatment Mount Sinai Journal of Medicine 2009; 76(2): 173-81. https://doi.org/10.1002/msj.20099

11. de Guise E, Gosselin N, Leblanc J, Champoux MC, Couturier C, Lamoureux J, et al. Clock drawing and minimental state examination in patients with traumatic brain injury. Applied Neuropsychology 2011; 18(3): 179-90. https://doi.org/10.1080/09084282.2011.595444

12. Elhan AH, Kutlay S, Kucukdeveci AA, Cotuk C, Ozturk G, Tesio L, et al. Psychometric properties of the Mini-Mental State Examination in patients with acquired brain injury in Turkey. Journal of Rehabilitation Medicine 2005; 37(5): 306-11. https://doi.org/10.1080/16501970510037573

13. Lee CN, Koh YC, Moon CT, Park DS, Song SW. Serial Mini-Mental Status Examination to evaluate cognitive outcome in patients with traumatic brain injury. Korean Journal of Neurotrauma 2015; 11(1): 6-10. https://doi.org/10.13004/ kjnt.2015.11.1.6

14. Rezaei S, Asgari K, Yousefzadeh S, Mousavi H, Kazemnejad E. Identifying risk factors for incidence of mental disorders after traumatic brain injury. Zahedan Journal of Research in Medical Sciences 2014; 16(9): 45-54.
15. Buhl I, Pallesen H. Early rehabilitation of patients with severe acquired brain injury: strategies to promote participation. Scandinavian Journal of Occupational Therapy 2015; 22(3): 181-95. https://doi.org/10.3109/11038128.2015.1008567

16. Flannery J. Using the levels of cognitive functioning assessment scale with patients with traumatic brain injury in an acute care setting. Rehabilitation Nursing 1998; 23(2): 88-94. https://doi.org/10.1002/j.2048-7940.1998.tb02136.x

17. Schlenstedt C, Paschen S, Kruse A, Raethjen J, Weisser B, Deuschl G. Resistance versus balance training to improve postural control in Parkinson's disease: a randomized rater blinded controlled study. PLoS One 2015; 10(10): e0140584. https://doi.org/10.1371/journal.pone.0140584

18. Leon-Carrion J, Dominguez-Morales MR, Barroso y Martin JM, Leon-Dominguez U. Recovery of cognitive function during comprehensive rehabilitation after severe traumatic brain injury. Journal of Rehabilitation Medicine 2012; 44(6): 505-11. https://doi.org/10.2340/16501977-0982

19. Spitz G, Ponsford J, Maller J. Association between cognitive performance and functional outcome following traumatic brain injury: a longitudinal multilevel examination. Journal of Neuropsychology 2012; 26: 604-12. https://doi.org/ $10.1037 / \mathrm{a} 0029239$

20. Saverino A, Waller D, Rantell K, Parry R, Moriarty A, Playford ED. The role of cognitive factors in predicting balance and fall risk in a neuro-rehabilitation setting. PLoS One 2016; 11(4): e0153469. https://doi.org/10.1371/journal. pone. 0153469

E. Lendraitienė, U. Buraitytė, D. Petruševičienė, L. Varžaitytė

PUSIAUSVYROS IR PAŽINIMO FUNKCIJŲ ATGAVIMO SASAJA, TAIKANT KINEZITERAPIJA ASMENIMS, PATYRUSIEMS GALVOS SMEGENŲ TRAUMA

\section{Santrauka}

Tyrimo tikslas. Nustatyti pusiausvyros ir pažinimo funkcijų atgavimo sąsają, taikant kineziterapiją asmenims, patyrusiems galvos smegenų traumą.

Tyrimo metodai. Tyrime dalyvavo 25 asmenys, patyrę galvos smegenų traumą. Tiriamieji pagal traumos sunkumą buvo suskirstyti ị dvi grupes: pirmają grupę sudarė 15 tiriamųjų, patyrusių vidutinio sunkumo galvos smegenų traumą, o antrają - 10 tiriamujjų, patyrusių sunkią traumą. Visi tiriamieji turẻjo pažinimo funkcijų ir pusiausvyros sutrikimų. Buvo vertinamos pažinimo funkcijos pagal trumpaji protinès būklès tyrimo testą (MMSE), pažinimo (sąmoningumo) lygis - pagal Rancho Los Amigos (RLA) skalę ir pusiausvyra - pagal Fullerton testą. Statistinè duomenų analizè atlikta naudojant SPSS.21 for Windows statistini programų paketa ir Microsoft Exel 2010 programą.

Tyrimo rezultatai ir išvados. 1. Po kineziterapijos pagerejo asmenų, patyrusių vidutinio sunkumo ir sunkią galvos smegenų traumą, pusiausvyra. 2. Kineziterapija pagerino asmenų, patyrusių vidutinio sunkumo ir sunkią galvos smegenų traumą pažinimo funkcijas. 3. Asmenims, patyrusiems vidutinio sunkumo ir sunkią galvos smegenų traumą, nenustatytas statistiškai reikšmingas ryšys tarp pusiausvyros ir pažinimo funkcijų atsigavimo. 4. Ieškant koreliacijos tarp atskirų Fullerton pusiausvyros testo ir trumpojo protinès būklès tyrimo testo užduočių, abiejose grupėse tarp kai kurių iš jų gautas statistiškai patikimas ryšys.

Raktažodžiai: galvos smegenų trauma, pusiausvyra, pažinimo funkcijos, kineziterapija.

Gauta:

Priimta spaudai:

20180701 